\title{
Analysis of different DNA fragments of Corynebacterium glutamicum complementing dapE of Escherichia coli
}

\author{
Axel Wehrmann, Lothar Eggeling and Hermann Sahm \\ Author for correspondence: Lothar Eggeling. Tel: +49 246161 5132. Fax: +492461 612710.
}

Institut für Biotechnologie, Forschungszentrum Jülich GmbH, D-52425 Jülich, Germany

\begin{abstract}
In Corynebacterium glutamicum L-lysine is synthesized simultaneously via the succinylase and dehydrogenase variant of the diaminopimelate pathway. Starting from a strain with a disrupted dehydrogenase gene, three differentsized DNA fragments were isolated which complemented defective Escherichia coli mutants in the succinylase pathway. Enzyme studies revealed that in one case the dehydrogenase gene had apparently been reconstituted in the heterologous host. The two other fragments resulted in desuccinylase activity; one of them additionally in succinylase activity. However, the physical analysis showed that structural changes had taken place in all fragments. Using a probe derived from one of the fragments we isolated a $3.4 \mathrm{~kb}$ BamHI DNA fragment without selective pressure (by colony hybridization). This was structurally intact and proved functionally to result in tenfold desuccinylase overexpression. The nucleotide sequence of a $1966 \mathrm{bp}$ fragment revealed the presence of one truncated open reading frame of unknown function and that of dapE encoding $N$-succinyl diaminopimelate desuccinylase (EC 3.5.1.18). The deduced amino acid sequence of the dapE gene product shares $23 \%$ identical residues with that from $E$. coli. The $C$. glutamicum gene now available is the first gene from the succinylase branch of lysine synthesis of this biotechnologically important organism.
\end{abstract}

Keywords: lysine synthesis, heterologous complementation, diaminopimelate desuccinylase, Corynebacterium glutamicum

\section{INTRODUCTION}

Bacteria synthesize L-lysine via the diaminopimelate (DAP) pathway. Three variants of this pathway are now known which are established in different organisms (Gilvarg, 1959; Weinberger \& Gilvarg, 1970; White, 1983). A peculiarity is the lysine synthesis of the Grampositive Corynebacterium glutamicum, which is used for industrial production of L-lysine (Eggeling, 1994). Interestingly, in this organism two of the three possible variants are present simultaneously, namely the succinylase variant and the dehydrogenase variant (Fig. 1). Both variants are actually used simultaneously in vivo as shown by the ${ }^{13} \mathrm{C}$ tracer technique (Sonntag et al., 1993). The flux distribution via both variants is ammonium-

Abbreviation: DAP, diaminopimelate.

The EMBL accession number for the sequence reported in this paper is $\times 81379$. dependent and the overall contribution of the succinylase branch for lysine synthesis is about $70 \%$.

We and others (Ishino et al., 1988; Yeh et al., 1988; Cremer et al., 1990, 1991) have cloned all genes of the DAP pathway via the dehydrogenase variant. We found that the dehydrogenase is dispensible for growth and that its oversynthesis has no positive effect on lysine overproduction, whereas other enzymes increase lysine formation (Cremer et al., 1991). To perform similar experiments with enzymes of the succinylase variant the respective genes are required. However, in two attempts to clone genes of either the succinylase or the dehydrogenase variant, only the $d d b$ gene (dehydrogenase) was isolated (Ishino et al., 1988; Yeh et al., 1988). In these experiments dapD mutants of Escherichia coli (succinylase deficient) were used, showing that the dap $D$ mutation can be favourably bypassed in E. coli by $d d h$ of $C$. glutamicum. However, in order to isolate a gene of the succinylase variant, $E$. coli mutants must be used, because no $C$. 


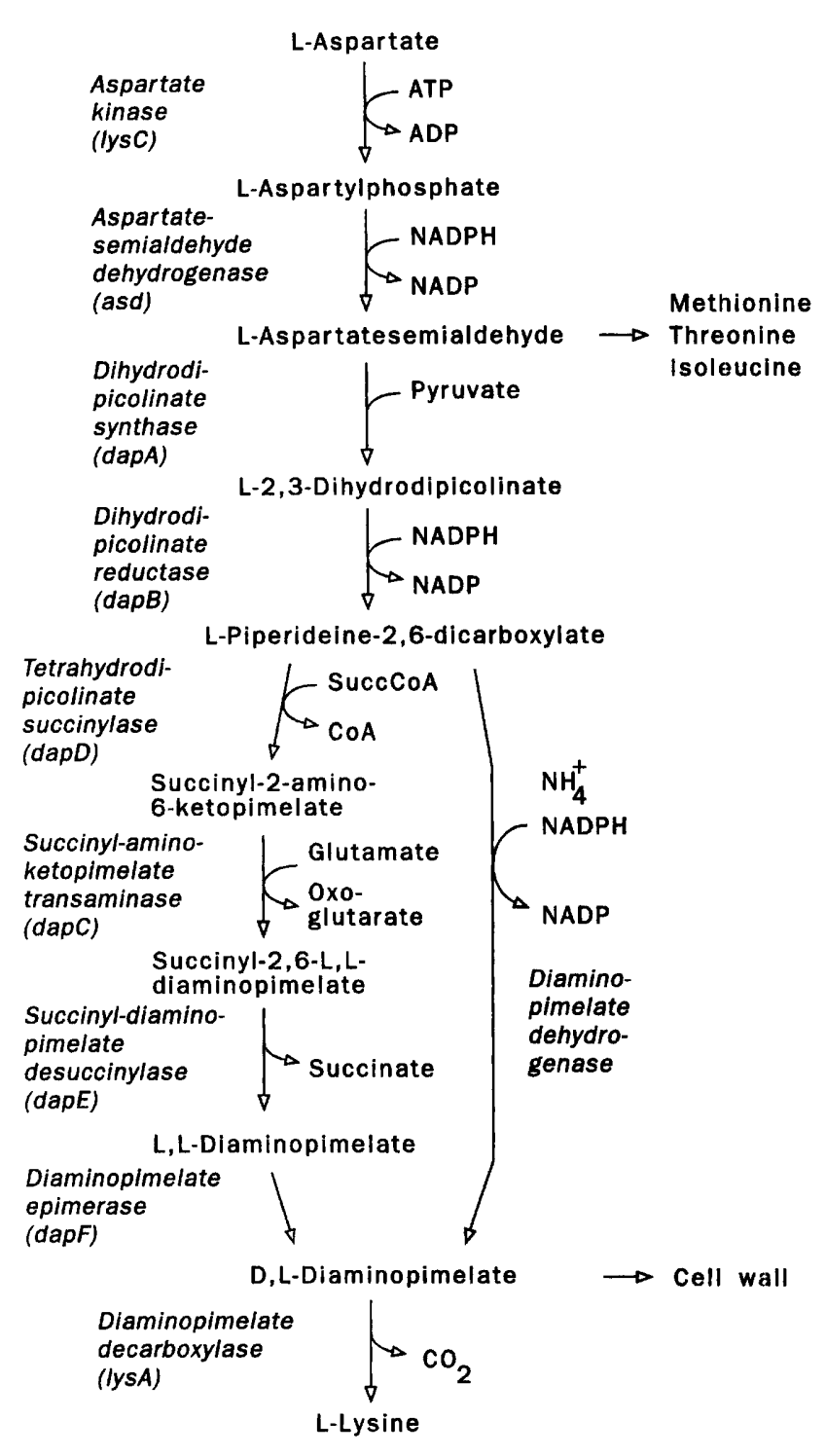

Fig. 1. The split pathway of lysine synthesis in Corynebacterium glutamicum. Synthesis of meso-diaminopimelate via the succinylase variant (left) and the dehydrogenase variant (right).

glutamicum DAP-auxotrophs can be isolated (Yeh et al., 1988), probably due to the inability of $C$. glutamicum to take up DAP. In addition, it is not possible to design and use degenerate oligonucleotides for cloning, since currently the dapD sequences known from three bacteria do not reveal well-conserved domains (Richaud et al., 1984; Denich et al., 1991; Baril et al., 1992) and the sequences for $d a p E$ and $d a p F$ are known only for E. coli (Bouvier et al., 1992; Richaud et al., 1987).

The recent availability of a $d d b$ mutant of $C$. glutamicum, constructed by vector integration into the $d d b$ gene (Schrumpf et al., 1991), prompted us to start a new attempt at isolating genes of the C. glutamicum succinylase variant. Using genomic DNA from this mutant the appropriate $E$. coli mutants should be complemented by either dapE or dapD of $C$. glutamicum. We describe our findings using this approach.

\section{METHODS}

Bacterial strains and growth conditions. All strains and plasmids used are listed in Table 1. Escherichia coli was grown on LB medium for cloning purposes (Lennox, 1955), or on BHI medium (Difco) for complementation and enzyme measurements. Corynebacterium glutamicum was grown on CgIII (Menkel et al., 1989). When appropriate, kanamycin $\left(50 \mu \mathrm{g} \mathrm{ml}^{-1}\right)$, ampicillin $\left(40 \mu \mathrm{g} \mathrm{m}^{-1}\right)$ or DAP $\left(50 \mu \mathrm{g} \mathrm{ml}^{-1}\right)$ was added. All strains were grown aerobically at $30^{\circ} \mathrm{C}$ except for E. coli DH5 and E. coli NM522, which were incubated at $37^{\circ} \mathrm{C}$.

Genetic engineering. DNA was isolated from C. glutamicum by a modified alkaline extraction procedure with lysozyme (Schrumpf $e t$ al., 1991). All enzymes used were obtained from Boehringer and used as instructed by the manufacturer. DNA fragments were isolated and purified by using Geneclean (Dianova). For DNA hybridization according to Southern (1975), Nytran 13 nylon membranes (Schleicher and Schüll) were used. E. coli DH5 and NM522 were transformed by the $\mathrm{CaCl}_{2}$ method, whereas electroporation was used to transform C. glutamicum (Liebl et al., 1989).

Complementation of $\boldsymbol{E}$. coli DAP auxotrophs. In order to establish a cosmid genomic gene bank, total DNA was isolated from C. glutamicum AS70 partially digested with Sau3A and ligated into BamHI-restricted pHC79. Using the DNA Packaging Kit (Boehringer) the gene bank was established in E. coli DH5. Transformation of the DAP auxotrophs E. coli RDD32 and RDE51 was done by the following procedure. LB medium plus DAP $(50 \mathrm{ml})$ was inoculated and cells grown overnight at $30^{\circ} \mathrm{C} ; 10 \mathrm{ml}$ of this culture was used to inoculate $400 \mathrm{ml} \mathrm{LB}$ medium plus DAP and incubation was continued. The culture was harvested at $\mathrm{OD}_{600} 0.5$ and washed three times with ice-cold glycerol $(10 \%, \mathrm{w} / \mathrm{v})$. The cell pellet was diluted with ice-cold glycerol $(10 \%, \mathrm{w} / \mathrm{v})$ to obtain a final volume of $1 \mathrm{ml}$, and $100 \mu \mathrm{l}$ aliquots were frozen at $-70^{\circ} \mathrm{C}$. For electroporation, $1 \mu \mathrm{l}$ DNA

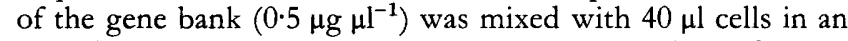
ice-cold sterile electroporation cuvette $(2 \mathrm{~mm}$ electrode gap, Bio-Rad) and pulsed (Bio-Rad, Gene Pulser plus Pulse Controller with the settings $2500 \mathrm{~V}, 25 \mu \mathrm{F}$ and $200 \Omega$ ). Immediately after the pulse $1 \mathrm{ml}$ prewarmed $\left(30^{\circ} \mathrm{C}\right) \mathrm{BHI}$ medium was added and the suspension was transferred into a tube containing another $1 \mathrm{ml}$ of prewarmed $\mathrm{BHI}$. After shaking at $30^{\circ} \mathrm{C}$ for $45 \mathrm{~min}, 10 \mu \mathrm{l}$ (E. coli RDD32) or $100 \mu \mathrm{l}$ (E. coli RDE51) aliquots were plated on selective agar plates containing ampicillin. Growth was checked after 1,2 and $4 \mathrm{~d}$.

Colony hybridization. A partial genomic gene bank, consisting of C. glutamicum ATCC 13032 BamHI DNA fragments of $2 \cdot 5-4 \cdot 3 \mathrm{~kb}$ inserted in pUC19, was established in E. coli NM522. A total of 740 colonies carrying recombinant plasmids (as confirmed by $\alpha$-complementation) were transferred on to a nylon membrane (PALL). Denaturation, washing and hybridization with the digoxigenin-labelled probe was performed as described in the standard procedure of the nonradioactive DNA Labelling and Detection Kit from Boehringer.

DNA sequencing and analysis. Deletion clones were prepared by exonuclease III treatment (Promega) of both strands of the $3.4 \mathrm{~kb}$ Bam HI dapE fragment in pUC19. The nucleotide sequence was determined by the method of Sanger et al. (1977) with Sequenase version 2.0 from US Biochemicals. Sequence data were compiled and analysed using the HUSAR program package, release 2.0 (EMBL).

Enzyme assays. Cells were washed with $0.9 \% \mathrm{NaCl}$, resuspended in $20 \mathrm{mM}$ Tris/ $\mathrm{HCl} \mathrm{pH} 8$, and disrupted by sonication. The homogenate was centrifuged for $30 \mathrm{~min}$ at $12000 \mathrm{~g}$, and the resulting extract was used to determine DAP 
Table 1. Bacterial strains and plasmids

\begin{tabular}{|c|c|c|}
\hline Strain & $\begin{array}{c}\text { Relevant } \\
\text { genotype/phenotype }\end{array}$ & Source/reference \\
\hline \multicolumn{3}{|l|}{ E. coli } \\
\hline DH5 & $\begin{array}{l}\text { thi-1 end } A \mathrm{R} 1 \mathrm{gyr} A 96 \mathrm{~F}^{-} \text {relA1 } \\
\sup E 44 \operatorname{rec} A 1 \text { bsdR } 17\left(\mathrm{r}^{-} \mathrm{m}^{+}\right)\end{array}$ & Hanahan (1985) \\
\hline NM522 & $\begin{array}{l}\text { supE thi } \Delta(\text { lac-pro } A B) \Delta b s d-5 \\
\left(\mathrm{r}^{-} \mathrm{m}^{-}\right)\left\{\mathrm{F}^{\prime} \text { pro } A B\right. \\
\left.\text { lac } I^{\mathrm{q}} \mathrm{Z} \Delta \mathrm{M} 15\right\}\end{array}$ & Gough \& Murray (1983) \\
\hline RDD32 & $\begin{array}{l}\operatorname{araD139} \text { thi } \Delta(\text { lac }) \mathrm{U} 168, \operatorname{str} A \\
\quad \text { dapD:: MuCts }\end{array}$ & Richaud et al. (1981) \\
\hline RDE51 & $\begin{array}{l}\operatorname{araD139} \text { thi } \Delta(\text { lac }) \mathrm{U} 168 \text { str } A \\
\operatorname{dap} E: \text { :MuCts }\end{array}$ & Richaud et al. (1981) \\
\hline \multicolumn{3}{|l|}{ C. glutamicum } \\
\hline ATCC 13032 & Wild-type, $\mathrm{Nx}^{\mathrm{r}}$ & Abe et al. (1967) \\
\hline AS70 & ATCC $13032 d d b::$ pEMddhint & Schrumpf et al. (1991) \\
\hline \multicolumn{3}{|l|}{ Plasmids } \\
\hline pHC79 & cos, $\mathrm{Ap}^{\mathrm{r}} \mathrm{Tc}^{\mathrm{r}}$, ori $V_{E . c .}$ & Hohn \& Collins (1980) \\
\hline pUC18/pUC19 & $A p^{r}$, ori $V_{E . c .}$ & Yanisch-Perron et al. (1985) \\
\hline pTG1228 & $\mathrm{Ap}{ }^{\mathrm{r}}, d d b^{+}$ & Transgene \\
\hline $\mathrm{pJC1}$ & $\begin{array}{l}\text { Shuttle vector, } \mathrm{Km}^{\mathrm{r}} \text {, ori } V_{E . c .} \text {. } \\
\text { ori } V_{\text {C.g. }}\end{array}$ & Cremer et al. (1990) \\
\hline $\mathrm{pD} 02$ & $\begin{array}{l}\mathrm{Ap}^{\mathrm{r}}, \text { dap } D^{+} \text {dap } E^{+}, \mathrm{pHC} 99 \\
\text { with } C . \text { glutamicum } 33.5 \mathrm{~kb} \\
\text { fragment }\end{array}$ & This work \\
\hline pDE07 & $\begin{array}{l}\mathrm{Ap}^{\mathrm{r}} \text {, dap } D^{+} \text {dap } E^{+}, \mathrm{pHC} 99 \\
\text { with } C . \text { glutamicum } 34 \mathrm{~kb} \\
\text { fragment }\end{array}$ & This work \\
\hline pJC dapDE BamHI 2.85 & $\begin{array}{l}\mathrm{Km}^{\mathrm{r}} \text {, dapD } D^{+} \text {dap } E^{+}, \mathrm{pJC1} \text { with } \\
\text { C. glutamicum } 2 \cdot 85 \mathrm{~kb} \text { Bam } \mathrm{HI} \\
\text { fragment from } \mathrm{pDE} 07\end{array}$ & This work \\
\hline pE015 & $\begin{array}{l}\mathrm{Ap}^{\mathrm{r}}, \text { dap } E^{+}, \mathrm{pHC} 79 \text { with } C . \\
\text { glutamicum } 31 \mathrm{~kb} \text { fragment }\end{array}$ & This work \\
\hline PJC dapE 1.9 & $\begin{array}{l}\mathrm{Km}^{\mathrm{r}} \text {, dap } E^{+}, \mathrm{pJC1} \text { with } C \text {. } \\
\text { glutamicum dap } E 1.9 \mathrm{~kb} \\
\text { fragment from } \mathrm{pE} 015\end{array}$ & This work \\
\hline pJC dapE BamHI 3.4 & $\begin{array}{l}\mathrm{Km}^{\mathrm{r}} \text {, dap } E^{+}, \mathrm{pJC1} \text { with } C \text {. } \\
\text { glutamicum dapE } 3.4 \mathrm{~kb} \\
\text { BamHI fragment }\end{array}$ & This work \\
\hline
\end{tabular}

dehydrogenase activity (EC 1.4.1.16) (Cremer et al., 1988). Gel filtration of the crude extract, substrate synthesis for the succinylase assay, and the activity measurements of succinylase (DapD) and $N$-succinyl diaminopimelate desuccinylase (DapE; EC 3.5.1.18) were performed as described previously (Schrumpf et al., 1991). Protein concentrations were determined by the biuret reaction (Gornall et al., 1949).

\section{RESULTS}

\section{Complementation of $E$. coli DAP auxotrophs with DNA from C. glutamicum ddh}

A cosmid genomic gene bank of $C$. glutamicum AS70 (with $d d h$ interrupted by vector sequences) was constructed in pHC79 using E. coli DH5 as host. From this bank we isolated 15 cosmids which were able to complement $E$. coli
RDD32 (dapD) or E. coli RDE51 (dapE). By retransformation, three types of complementing cosmids could be identified which conferred a stable DAP prototrophy. Type I, represented by cosmids pD02 and pD03, showed complementation of both E. coli mutants, while pDE07 (the only type II cosmid) also showed crosscomplementation but shared no common restriction pattern with type I cosmids. Cosmid pE015, as well as cosmids pE06, pE09, pE011 and pE012 (type III cosmids), complemented E. coli $\operatorname{RDE} 51$ (dapE) only. It is noteworthy that all type I and type II cosmids led to better growth of the $E$. coli mutants (colonies appeared after 1-2 d incubation) than type III cosmids (colonies appeared only after $4 \mathrm{~d}$ incubation). Therefore, we initially chose the type I cosmid pD02, complementing both $E$. coli mutations, for further analysis. However, after a series 
Table 2. Enzyme activities in C. glutamicum due to a subclone obtained from cosmid pDE07 (type II)

Strains were grown overnight in CgIII medium. The activity is expressed in $\mu \mathrm{mol} \mathrm{min}^{-1}$ (mg protein $)^{-1}$. Results are from three separate experiments. ND, Not determined.

\begin{tabular}{|lccc|}
\hline Strain & $\begin{array}{c}\text { Succinylase } \\
\text { (DapD) }\end{array}$ & $\begin{array}{c}\text { Desuccinylase } \\
\text { (DapE) }\end{array}$ & $\begin{array}{c}\text { Dehydrogenase } \\
\text { (Ddh) }\end{array}$ \\
\hline ATCC 13032(pJC1) & $0 \cdot 005$ & $0 \cdot 021$ & $0 \cdot 114$ \\
ATCC 13032(pJC dapDE BamHI 2.85) & $0 \cdot 027$ & $0 \cdot 148$ & $0 \cdot 148$ \\
ATCC 13032(pJC dapDE BamHI 2.85 inv $)$ & $0 \cdot 028$ & $0 \cdot 156$ & $0 \cdot 176$ \\
AS70 $(d d b)$ & $0 \cdot 005$ & ND & $<0 \cdot 0005$ \\
\hline
\end{tabular}

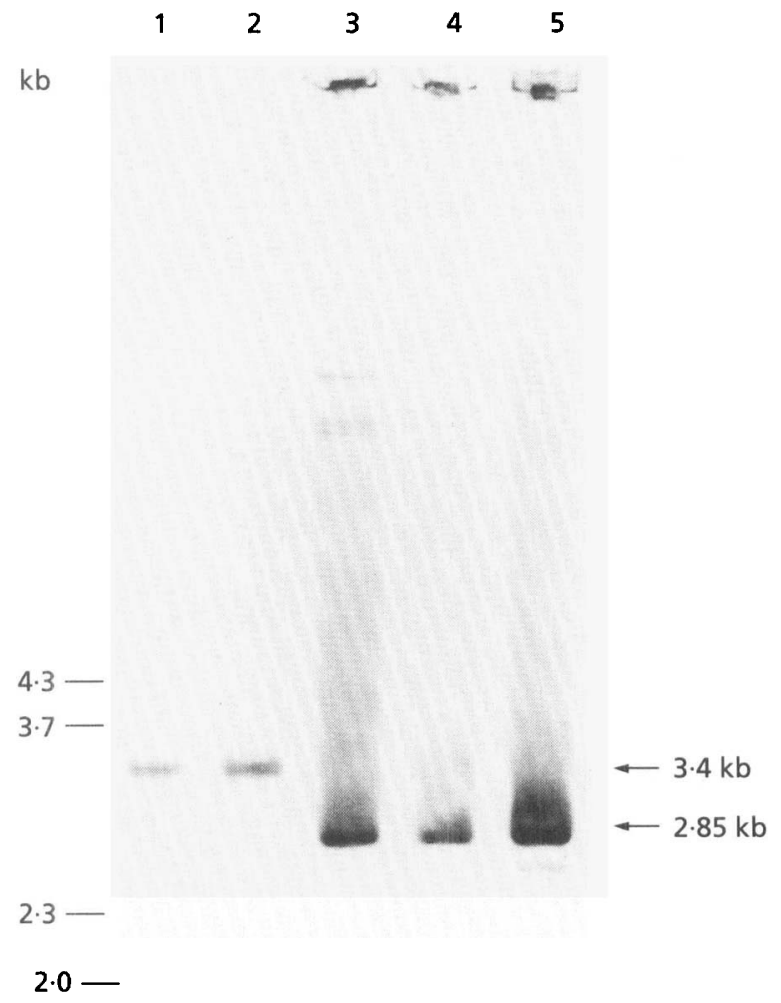

Fig. 2. Southern blot analysis of genomic DNA from $C$. glutamicum strains ATCC 13032 (lane 1) and AS70 (lane 2), cosmid DNA of pDE07 (lane 3) and pE015 (lane 4), and plasmid DNA of pUC19 dapDE 2.85 (lane 5). DNA was BamHI-restricted and probed with a digoxigenin-labelled internal $0.9 \mathrm{~kb}$ Sall fragment isolated from the $2.85 \mathrm{~kb}$ dapDE BamHI fragment.

of biochemical and genetic investigations we had to assume (not shown) that in the type I cosmids the $d d b$ gene was functionally reconstituted.

\section{Analysis of type II cosmid pDE07}

We investigated cosmid pDE07 in detail since it enabled growth of the $E$. coli strains with the dapD or dapE mutation, suggesting that the two genes might be linked to each other. For subcloning, cosmid pDE07 was digested with BamHI, fragments were ligated with pUC18, and after transformation 38 ampicillin-resistant DAP-prototrophic clones of RDD32 were obtained. Several plasmids were isolated and proved also to transform RDE51 to DAP prototrophy. The plasmids contained a $2.85 \mathrm{~kb} \mathrm{BamHI}$ fragment which was ligated into the $C$. glutamicum $/ E$. coli shuttle vector $\mathrm{PJC1}$ yielding pJC dapDE BamHI 2.85 and pJC1 dapDE BamHI $2 \cdot 85_{\text {inv }}$ (with the insert in the inverse orientation). After introduction of these plasmids into C. glutamicum ATCC 13032 , enzyme activities in the recombinant strains were determined (Table 2). In this case dehydrogenase (Ddh) activity was comparable to the wild-type level, and the expected DapD oversynthesis and that of DapE was also obtained. To probe the integrity of the cloned fragment a Southern blot analysis with chromosomal DNA of the wild-type was performed. This analysis, however, showed hybridization to a $3.4 \mathrm{~kb} \mathrm{Bam} \mathrm{HI}$ fragment (Fig. 2) instead of the expected cloned $2.85 \mathrm{~kb} \mathrm{BamHI}$ fragment. Therefore, the isolated $B a m \mathrm{HI}$ fragment was structurally altered, and we had to concentrate on a type III cosmid.

\section{Analysis of type III cosmid pE015}

Subcloning of pE015 led to a $1.9 \mathrm{~kb}$ Sau3A fragment inserted in vector $\mathrm{pJC1}$. The restriction pattern of this fragment resembled in part that of the $2.85 \mathrm{~kb} \mathrm{BamHI}$ fragment originating from type II cosmid. Its structural integrity was confirmed by extended Southern blot studies (data not shown). With the aim to clone dapD also, and based on the assumption that dapD and dapE might be located close to each other, we isolated the dapE locus again, but avoided a functional selection.

\section{Isolation of dapE by colony hybridization}

In order to isolate the chromosomal $3.4 \mathrm{~kb} B a m \mathrm{HI}$ fragment a partial gene bank consisting of BamHI fragments of C. glutamicum wild-type DNA was constructed in pUC19. This gene bank was screened with an $800 \mathrm{bp} E c o \mathrm{RI} /$ XboI internal fragment of the $1.9 \mathrm{~kb}$ dapE complementing insertion originating from type III cosmid pE015 (see Methods). Three of the 740 colonies tested reacted positively and plasmid isolation gave the intact $3.4 \mathrm{~kb}$ Bam HI fragment inserted in pUC19. This 

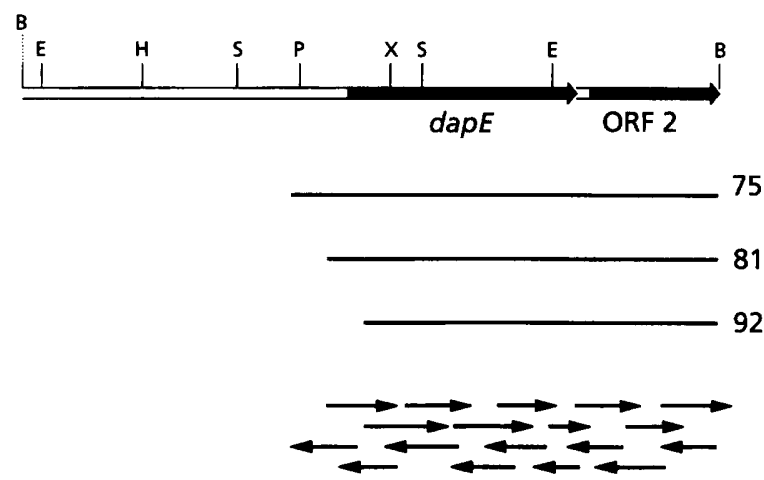

$\Gamma$
$3 \quad \mathrm{kbp}$
Growth

without

DAP

$+$

$+$

$+$

$-$

\begin{abstract}
Fig. 3. Map of the chromosomal DNA of $C$. glutamicum in pUC19 dapE BamHI 3.4. Top: restriction map. Abbreviations: $B, B a m H I ; E$, EcoRI; H, HindllI; K, Kpnl; P, Pstl; S, Sall; X, Xhol. Centre: extent of exonuclease-IIIgenerated deletions of pUC19 dapE BamHI 3.4. Numbers refer to deletion clones $\Delta 75$, $\Delta 81$ and $\Delta 92$. The DapE phenotype conferred on strain $E$. coli RDE51 is indicated. Bottom: sequencing strategy using exonuclease-III-generated deletions.
\end{abstract}

plasmid, pUC19 dapE BamHI $3 \cdot 4$, was able to complement $E$. coli RDE51 (dapE), but, unexpectedly, not $E$. coli RDD32 (dapD). However, in this case, DNA hybridization analysis confirmed the structural integrity of this fragment (data not shown). The fragment was ligated with pJC1 to yield pJC dapE BamHI 3.4, which was used to transform the wild-type of C. glutamicum to kanamycin resistance. In the resulting recombinant strain the desuccinylase activity was determined. The specific

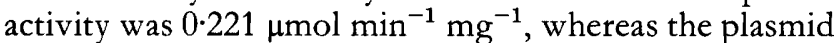
without insert yielded a specific activity of $0.021 \mu \mathrm{mol}$ $\mathrm{min}^{-1} \mathrm{mg}^{-1}$. This DapE oversynthesis is functional proof that dapE resides on the cloned fragment. With the same insert in the opposite orientation with respect to the vector a similar high specific activity was obtained, verifying that $d a p E$ was cloned with its functional promoter. In order to localize the dapE gene more precisely within the $3.4 \mathrm{~kb}$ Bam $\mathrm{HI}$ fragment, exonucleaseIII-generated deletion clones were made and analysed for their dapE complementation ability (Fig. 3). While deletion $\Delta 81$ was still able to complement dapE, the 205 bp shorter deletion fragment $\Delta 92$ lacked this ability.

\section{Nucleotide sequence analysis}

The complete nucleotide sequence of fragment $\Delta 81$ was determined on both strands using the sequencing strategy shown in Fig. 3. The sequence obtained is shown in Fig. 4. Two open reading frames (ORFs) were found, extending from nucleotide 162 to nucleotide 1268 and from nucleotide 1333 to the end of the fragment (nucleotide 1966). Since the complete ORF spans the DNA region functionally proven to result in desuccinylase activity, it was designated dapE. Preceding dapE, a typical Shine-Dalgarno sequence, 5'-GTAGG-3' (Moran et al., 1982), is located 9 nucleotides in front of the most probable translational start site, GTG, at position 162 (Fig. 4). ORF2 starts downstream of dapE, following a short intergenic region of $61 \mathrm{bp}$. Due to the codon preference, which resembles moderately expressed genes of C. glutamicum (Eikmanns, 1992), and a perfect ribosomal binding site, 5'-AGGAGG-3', ORF2 most probably represents a coding region. Since we were not able to detect secondary structures reflecting a transcriptional termination site downstream of dapE, a transcriptional readthrough from dapE to ORF2 is possible. Comparison of the deduced amino acid sequences showed no significant identity with known proteins in the case of ORF2. However, DapE shares $23 \%$ identical amino acids with the corresponding polypeptide from E. coli (Bouvier et al., 1992). Assuming initiation at position GTG 162, the $C$. glutamicum dapE gene product consists of 369 amino acids, with a molecular mass of $39942 \mathrm{Da}$, which is comparable with that of 41129 Da deduced for the $E$. coli polypeptide.

\section{DISCUSSION}

Although C. glutamicum has been biochemically proven to possess (Schrumpf et al., 1991) and use (Sonntag et al., 1993) the succinylase pathway, in two attempts to clone corresponding genes only $d d b$ of the dehydrogenase pathway was isolated (Ishino et al., 1988; Yeh et al., 1988). In this work we were again faced with considerable problems when starting with a dehydrogenase-negative strain. First, restoration of dehydrogenase activity in $E$. coli was obtained, and second, repeatedly structurally altered DNA fragments were found. It is unclear why both type I cosmids carry a functional $d d b$ gene. Most probably homologous recombination in the $E$. coli host resulted in deletion of the integration vector pEM1, thereby restoring dehydrogenase activity. This points to strong selection pressure by the DAP-auxotrophic mutants.

With respect to the structural alterations of fragments carrying genes of the succinylase variant, only cloning without functional selection was successful in obtaining a larger fragment with intact dapE. This could in principle be due to the possibility that the gene products of dapD and dapE itself or that of a closely related gene(s) are disadvantageous for the host upon overexpression. It is known that dapE of $E$. coli is able to suppress a mutation of the heat-shock gene grpE (Wu et al., 1992), which at 


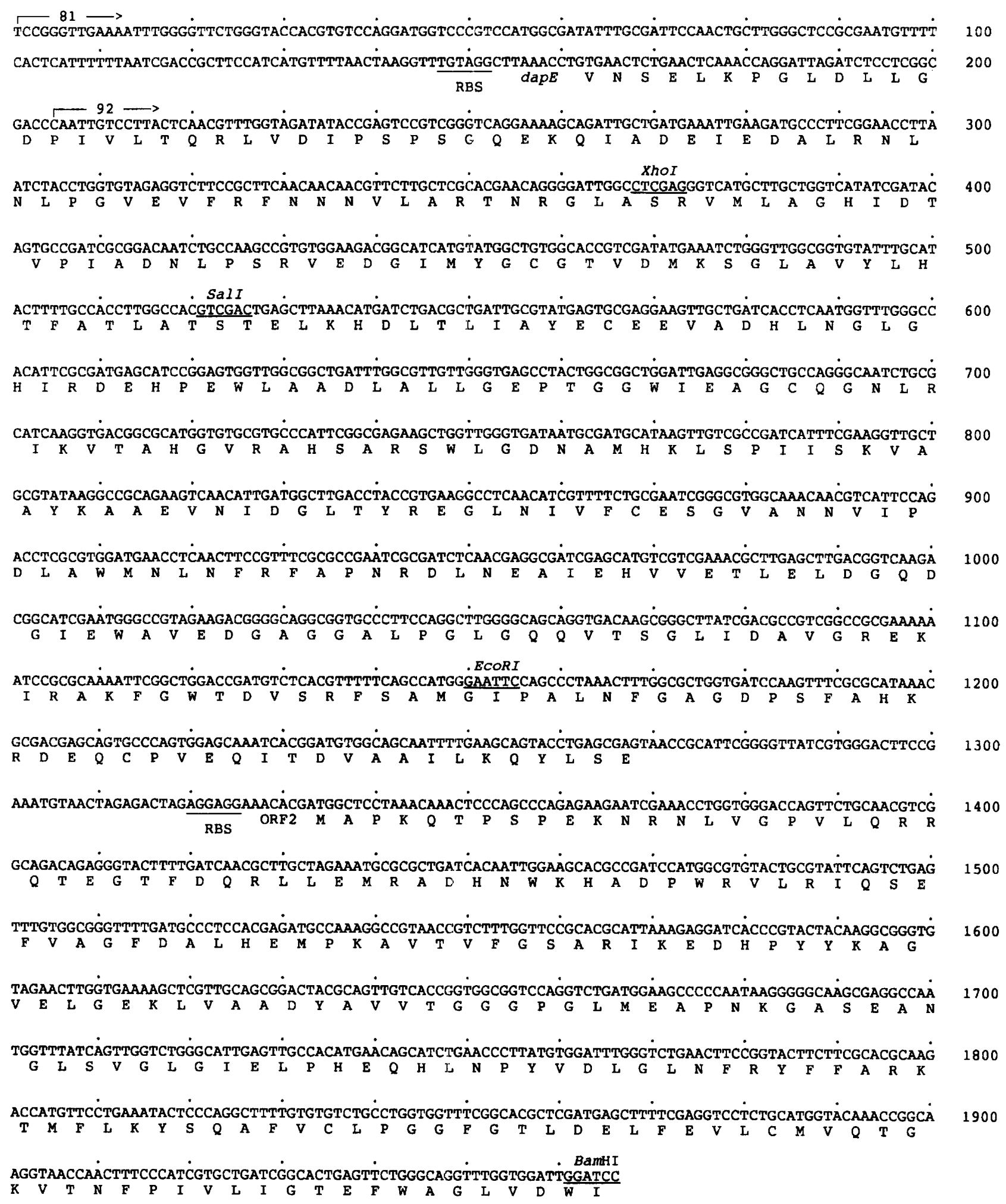

Fig. 4. Sequence of the dapE gene locus, with deduced polypeptide sequences and selected restriction sites. Putative ribosome-binding sites (RBS) of the corresponding coding regions and starting points of the deletion clones $\Delta 81$ and $\Delta 92$ are indicated.

least shows that enzymes of the succinylase variant may have other as yet unknown functions. But in the case of dapE of $C$. glutamicum it seems to be neighbouring sequences which are responsible for problems in cloning. It is interesting that in spite of various attempts with a probe of the type II cosmid we failed to isolate dapD by 
hybridization (not shown). Due to this fact, together with the problems in cloning the large fragment with $\operatorname{dap} E$, and the type II cosmid complementing both $\operatorname{dap} \mathrm{D}$ and dapE, it is tempting to speculate that the difficulties in cloning can be attributed to an identical detrimental gene.

These discoveries might be one reason why Ishino $e t$ al. (1988) and Yeh et al. (1988) were not able to isolate succinylase genes. Another reason is the apparently poorer promoter recognition of certain C. glutamicum genes in $E$. coli. dap $E$ thus apparently leads only to weak expression in $E$. coli since growth due to the dapE-containing fragment only results after $4 \mathrm{~d}$. Similarly, other amino acid biosynthetic genes of $C$. glutamicum are only weakly expressed in E. coli, such as $i l v A$ and $i l v B N$ (Cordes et al., 1992), lys $C$ (Kalinowski et al., 1990), or dap $A$ and dapB (Cremer et al., 1990). The current mapped promoters of $C$. glutamicum lack the features typically attributed to $E$. coli $\sigma^{70}$ or $B$. subtilis $\sigma^{43}$ promoters (Schwinde et al., 1993) and no specific consensus sequence can be given to identify a possible promoter directly in front of dapE.

Heterologous complementation resulted above all in the DNA probe for cloning the structurally and functionally intact dapE gene. Analysis of the dapE sequence showed that the $N$-succinyldiaminopimelate desuccinylase (DapE) of C. glutamicum shares $23 \%$ identical amino acids with the only known corresponding polypeptide, whose gene was isolated from E. coli (Bouvier et al., 1992). This low, but significant, degree of identical residues was also reported for the polypeptides of other amino acid biosynthetic enzymes from C. glutamicum (LysC, Kalinowski et al., 1990; IlvA, Möckel et al., 1992; LeuA, Pátek et al., 1994), whereas higher identities were found if the polypeptides involved in central metabolism of both organisms are compared (Schwinde et al., 1993). This shows that in spite of the specific dehydrogenase pathway for Gram-positive bacteria, the DapE structure of $C$. glutamicum has evolved away from that of E. coli to the same extent as that of other amino acid biosynthesis genes. The cloning of dapE now achieved will permit further molecular studies on flow changes in the unusual lysine synthesis pathway of $C$. glutamicum. Moreover, a fine-structural analysis of a type II cosmid with succinylase and desuccinylase activity will enable further studies on the chromosomal loci of the respective genes.

\section{ACKNOWLEDGEMENTS}

The work described in this report is part of a joint project with DEGUSSA AG and was supported by grant 0310626 from the Bundesministerium für Forschung und Technologie.

\section{REFERENCES}

Abe, S., Takayama, K. \& Kinoshita, S. (1967). Taxonomical studies on glutamic acid-producing bacteria. $J$ Gen Appl Microbiol 13, 279-301.

Baril, C., Richaud, C., Fourné, G., Baranton, G. \& Saint Girons, I. (1992). Cloning of $d a p D$, aroD and asd of Leptospira interrogans serovar icterobaemorrbagiae, and nucleotide sequence of the asd gene. $J$ Gen Microbiol 138, 47-53.
Bouvier, J., Richaud, C., Higgins, W., Bögler, O. \& Stragier, P. (1992). Cloning, characterization, and expression of the dapE gene of Escherichia coli. J Bacteriol 174, 5265-5271.

Cordes, C., Möckel, B., Eggeling, L. \& Sahm, H. (1992). Cloning, organization and functional analysis of $i l v A$, ilvB and $i l v C$ genes from Corynebacterium glutamicum. Gene 112, 113-116.

Cremer, J., Treptow, C., Eggeling, L. \& Sahm, H. (1988). Regulation of enzymes of lysine biosynthesis in Corynebacterium glutamicum. $J$ Gen Microbiol 134, 3221-3229.

Cremer, J., Eggeling, L. \& Sahm, H. (1990). Cloning the dap $A$ dapB cluster of the lysine-secreting bacterium Corynebacterium glutamicum. Mol \& Gen Genet 220, 478-480.

Cremer, J., Eggeling, L. \& Sahm, H. (1991). Control of the lysine biosynthetic sequence in Corynebacterium glutamicum as analyzed by overexpression of the individual corresponding genes. Appl Environ Microbiol 57, 1746-1752.

Denich, K., O'Hanley, P. \& Lalonde, G. (1991). Cloning and sequence analysis of the DapD gene from Actinobacillus pleuropneumoniae. EMBL Database X63201.

Eggeling, L. (1994). Biology of L-lysine overproduction by Corynebacterium glutamicum. Amino Acids 6, 261-272.

Eikmanns, B. (1992). Identification, sequence analysis, and expression of a Corynebacterium glutamicum gene cluster encoding the three glycolytic enzymes glyceraldehyde-3-phosphate dehydrogenase, 3-phosphoglycerate kinase, and triosephosphate isomerase. $J$ Bacteriol 174, 6067-6086.

Gilvarg, C. (1959). N-Succinyl-L-diaminopimelic acid. J Biol Chem 234, 2955-2959.

Gornall, A. G., Bardawill, C. J. \& David, M. M. (1949). Determination of serum proteins by means of the biuret reaction. $J$ Biol Chem 77, 751-766.

Gough, J. A. \& Murray, N. E. (1983). Sequence diversity among related genes for recognition of specific targets in DNA molecules. $J$ Mol Biol 166, 1-19.

Hanahan, D. (1985). Techniques for transformation of E. coli. In DNA Cloning: a Practical Approach, vol. 1, pp. 109-136. Edited by D. M. Glover. Oxford: IRL Press.

Hohn, B. \& Collins, J. (1980). A small cosmid for efficient cloning of large DNA fragments. Gene 11, 291-298.

Ishino, S., Muzikami, T., Yamaguchi, K., Katsumata, R. \& Araki, K. (1988). Cloning and sequencing of the meso-diaminopimelate-Ddehydrogenase $(d d b)$ gene of Corynebacterium glutamicum. Agric Biol Chem 52, 2903-2909.

Kalinowski, J., Bachmann, B., Thierbach, G. \& Pühler, A. (1990). Aspartokinase genes $l_{s} C \alpha$ and $l_{y s} C \beta$ overlap and are adjacent to the aspartate $\beta$-semialdehyde dehydrogenase gene asd in Corynebacterium glutamicum. Mol \& Gen Genet 224, 317-324.

Lennox, E. S. (1955). Transduction of linked genetic characters of the host by bacteriophage P1. Virology 1, 190-206.

Liebl, W., Bayerl, A., Stillner, U. \& Schleifer, K. H. (1989). High efficiency electroporation of intact Corynebacterium glutamicum cells. FEMS Microbiol Lett 65, 299-304.

Menkel, E., Thierbach, G., Eggeling, L. \& Sahm, H. (1989). Influence of increased aspartate availability on lysine formation by a recombinant strain of Corynebacterium glutamicum and utilization of fumarate. Appl Environ Microbiol 55, 684-688.

Möckel, B., Eggeling, L. \& Sahm, H. (1992). Functional and structural analyses of threonine dehydratase from Corynebacterium glutamicum. J Bacteriol 174, 8065-8072.

Moran, C. P., Lang, N., LeGrice, S. F. J., Lee, G., Stephens, M., Sonenshein, A. L., Pero, J. \& Losick, R. (1982). Nucleotide 
sequences that signal the initiation of transcription and translation in Bacillus subtilis. Mol \& Gen Genet 186, 339-346.

Pátek, M., Krumbach, K., Eggeling, L. \& Sahm, H. (1994). Leucine synthesis in Corynebacterium glutamicum: enzyme activities, structure of leuA, and effect of leu $A$ inactivation on lysine synthesis. Appl Environ Microbiol 60, 133-140.

Richaud, F., Richaud, C., Haziza, C. \& Patte, J.-C. (1981). Isolement et purification de gènes d'Escherichia coli K12 impliqués dans la biosynthèse de la lysine. C R Acad Sci Ser III 293, 507-512.

Richaud, C., Richaud, F., Martin, C., Haziza, C. \& Patte, J. -C. (1984). Regulation of expression and nucleotide sequence of the Escherichia coli dapD gene. $J$ Biol Chem 259, 14824-14828.

Richaud, C., Higgins, W., Mengin-Lecreulx, D. \& Stragier, P. (1987). Molecular cloning, characterization, and chromosomal localization of $d a p F$, the Escherichia coli gene for diaminopimelate epimerase. J Bacteriol 169, 1454-1459.

Sanger, F., Nicklen, S. \& Coulson, A. R. (1977). DNA sequencing with chain-terminating inhibitors. Proc Natl Acad Sci USA 74, 5463-5467.

Schrumpf, B., Schwarzer, A., Kalinowski, J., Pühler, A., Eggeling, L. \& Sahm, H. (1991). A functionally split pathway for lysine synthesis in Corynebacterium glutamicum. J Bacteriol 173, 4510-4516.

Schwinde, J. W., Thum-Schmitz, N., Eikmanns, B. J. \& Sahm, H. (1993). Transcriptional analysis of the gap-pgk-tpi-ppc gene cluster of Corynebacterium glutamicum. J Bacteriol 175, 3905-3908.

Sonntag, K., Eggeling, L., De Graaf, A. A. \& Sahm, H. (1993). Flux partitioning in the split pathway of lysine synthesis in Corynebacterium glutamicum. Quantification by ${ }^{13} \mathrm{C}$ - and ${ }^{1} \mathrm{H}-\mathrm{NMR}$ spectroscopy. Eur J Biochem 213, 1325-1331.

Southern, E. M. (1975). Detection of specific sequences among DNA fragments separated by gel electrophoresis. J Mol Biol 98, 503-517.

Weinberger, S. \& Gilvarg, C. (1970). Bacterial distribution of the use of succinyl and acetyl blocking groups in diaminopimelic acid biosynthesis. J Bacteriol 101, 323-324.

White, P. J. (1983). The essential role of diaminopimelate dehydrogenase in the biosynthesis of lysine by Bacillus sphaericus. J Gen Microbiol 129, 739-749.

Wu, B., Georgopoulos, C. \& Ang, D. (1992). The essential Escherichia coli msgB gene, a multicopy suppressor of a temperaturesensitive allele of the heat shock gene $g r p E$, is identical to $d a p E$. $J$ Bacteriol 174, 5258-5264.

Yanisch-Perron, C., Vieira, J. \& Messing, J. (1985). Improved M13 phage cloning vectors and host strains: nucleotide sequences of the M13mp18 and pUC19 vectors. Gene 33, 103-109.

Yeh, P., Sicard, A. M. \& Sinskey, A. J. (1988). General organization of the genes specifically involved in the diaminopimelate-lysine biosynthetic pathway of Corynbacterium glutamicum. Mol \& Gen Genet 212, 105-111.

Received 25 April 1994; revised 8 August 1994; accepted 19 August 1994. 